\title{
NK-cell and T-cell functions in patients with breast cancer: effects of surgery and adjuvant chemo- and radiotherapy
}

\section{F Mozaffari', C Lindemalm', A Choudhury', H Granstam-Björneklett ${ }^{2}$, I Helander', M Lekander ${ }^{3}$, E Mikaelsson', B Nilsson ${ }^{4}$, M-L Ojutkangas ${ }^{5}$, A Österborg ${ }^{1,6}$, L Bergkvist ${ }^{5,7}$ and H Mellstedt ${ }^{*, 1,6}$}

IImmune and Gene Therapy Laboratory, Cancer Centre Karolinska, Karolinska University Hospital, SE-17I 76 Stockholm, Sweden; ${ }^{2}$ Department of Oncology, Central Hospital, SE-72I 89 Västerås, Sweden; ${ }^{3}$ Department of Clinical Neuroscience, Osher Center for Integrative Medicine and Section of Psychology, Karolinska Institutet, SE-I 7177 Stockholm, Sweden; ${ }^{4}$ Department of Cancer Epidemiology, Karolinska University Hospital, SE-I 7176

Stockholm, Sweden; ${ }^{5}$ Centre for Clinical Research, Uppsala University, Central Hospital, SE-72 I 89 Västerås, Sweden; ${ }^{6}$ Departments of Hematology and Oncology, Karolinska University Hospital, SE-I 7 I 76 Stockholm, Sweden; ${ }^{7}$ Department of Surgery and Centre for Clinical Research, Uppsala University, Central Hospital, SE-72189 Västerås, Sweden

Breast cancer is globally the most common malignancy in women. Her2-targeted monoclonal antibodies are established treatment modalities, and vaccines are in late-stage clinical testing in patients with breast cancer and known to promote tumour-killing through mechanisms like antibody-dependent cellular cytotoxicity. It is therefore increasingly important to study immunological consequences of conventional treatment strategies. In this study, functional tests and four-colour flow cytometry were used to detect natural killer (NK)-cell functions and receptors as well as T-cell signal transduction molecules and intracellular cytokines in preoperative breast cancer patients, and patients who had received adjuvant radiotherapy or adjuvant combined chemo-radiotherapy as well as in agematched healthy controls. The absolute number of NK cells, the density of NK receptors as well as in vitro quantitation of functional NK cytotoxicity were significantly higher in preoperative patients than the post-treatments group and controls. A similar pattern was seen with regard to T-cell signalling molecules, and preoperative patients produced significantly higher amounts of cytokines in NK and $T$ cells compared to other groups. The results indicate that functions of NK and T cells are well preserved before surgery but decrease following adjuvant therapy, which may speak in favour of early rather than late use of immunotherapeutic agents such as trastuzumab that may depend on intact immune effector functions.

British Journal of Cancer (2007) 97, I05-I I I. doi: I0.1038/sj.bjc.6603840 www.bjcancer.com

Published online 5 June 2007

(C) 2007 Cancer Research UK

Keywords: breast cancer; Her-2; T-cell signalling proteins; cytokines; NK cytotoxicity

Breast cancer (BC) is the most common malignancy in women and the principal cause of death from cancer among women globally (Bray et al, 2004). Despite impressive progress in diagnosis and treatment (Hudis, 2003), a substantial fraction of women fail conventional treatments (i.e. surgery, radiation treatment and/or chemotherapy) and ultimately relapse and die (Cheng et al, 2004). Her-2 targeting monoclonal antibodies such as trastuzumab, given as adjuvant therapy, have significantly improved the relapse-free survival of breast cancer patients (Chan et al, 2006). However, it is not yet clear whether adjuvant trastuzumab treatment ought to be incorporated early, that is together with chemotherapy, or late, that is after end of adjuvant chemo-radiotherapy (Gennari et al, 2004). In addition to their direct apoptosis-inducing effect on tumour cells via the antagonistic effect on critical tumour cell receptors, trastuzumab is known to promote immune-mediated

*Correspondence: Professor H Mellstedt, Department of Oncology (Radiumhemmet), Karolinska University Hospital, Stockholm SE-17176, Sweden; E-mail: hakan.mellstedt@karolinska.se

Received I0 January 2007; revised I 5 May 2007; accepted I 5 May 2007; published online 5 June 2007 destruction of tumour cells by mechanisms such as antibodydependent cellular cytotoxicity (ADCC) (Arnould et al, 2006), the mechanisms of which may be critically dependent on a functioning immune system. Additional immune function-dependent modalities for treatment of breast cancer that are currently in development include vaccines that induce active immunity against the cancer in patients (Yi et al, 2006). Thus, the above approaches to adjuvant therapy of breast cancer are impingent on the preservation of immune function in the patient during and following tumour debulking procedures.

Previous studies have reported that functional activity of natural killer (NK) cells is decreased and these cells undergo spontaneous apoptosis in patients with cancer (Konjevic and Spuzic, 1992; Bauernhofer et al, 2003). In contrast, increased NK-cell numbers and NK activity have also been reported in breast cancer and colon cancer before neo-adjuvant immunotherapy and correlated to time to treatment failure (Nicolini et al, 1996; Murta et al, 2000; Liljefors et al, 2003). Abnormalities in expression of activation molecules such as TCR , ZAP70 and p56 lck protein expression using western blot in BC (Kurt et al, 1998) as well as impaired expression of interferon- $\gamma($ IFN- $\gamma)$ in BC and lung cancer using enzyme-linked immunosorbent assay (Caras et al, 2004) have been described. 
However, to our knowledge no studies have examined the effects of conventional adjuvant breast cancer therapy on the immune function in these patients. Given the emerging adjuvant use of trastuzumab (as well as future vaccines), the present study was conducted to investigate the NK- and T-cell function in breast cancer patients before and after primary treatment with surgery and adjuvant chemo-radiotherapy with the intention of delineating any potential immune aberrations that may result from therapy. The results would be beneficial in providing a scientific basis to integrate adjuvant immunotherapy in an optimal way in such patients.

\section{MATERIALS AND METHODS}

\section{Patients and treatments}

Fifty women with $\mathrm{BC}$ and 11 healthy age-matched controls were included. The patients were all treated in the same surgery and oncology unit, according to the National Treatment Guidelines. Patients were treated according to the Helsinki declaration on the participation of human subjects in medical research and all blood samples were collected between 0800 and 0900 hours (to minimise diurnal influence) after obtaining informed consent as per protocols approved by the local ethical committee. Patient characteristics are shown in Table 1.

Blood samples from pretreatment $(n=9)$ (PT group) was drawn $1-3$ days before surgery and from post-treatment patients $(n=41)$ (RT, RT + CT groups). Median time was $45(5-100)$ and $120(54-$ 164) days after finishing adjuvant therapy.

About $50 \mathrm{~Gy}$ total radiation, fractioned in $2 \mathrm{~Gy}$ doses was delivered to the breast. Patients with lymph node involvement $(n=18)$ had additional radiation delivered to the adjacent lymph nodes. Twenty patients received radiotherapy alone (RT group) and 21 received a combination of radiation and chemotherapy

Table I Patient characteristics

\begin{tabular}{|c|c|c|c|}
\hline \multirow[b]{2}{*}{ Group } & \multirow[b]{2}{*}{$\begin{array}{c}\text { Pretreatment } \mathrm{t}^{\mathrm{a}} \\
(n=9)\end{array}$} & \multicolumn{2}{|c|}{$\begin{array}{c}\text { Post treatment } \\
(n=4 I)\end{array}$} \\
\hline & & $\begin{array}{c}\text { RT } \\
(n=20)\end{array}$ & $\begin{array}{l}R T+C T \\
(n=2 I)\end{array}$ \\
\hline Age (range) & $(43-75)$ & $(52-80)$ & $(38-69)$ \\
\hline \multicolumn{4}{|l|}{ Type of surgery } \\
\hline Mastectomy & - & 3 & 2 \\
\hline Breast conservation & - & 17 & 19 \\
\hline \multicolumn{4}{|l|}{ Lymph nodes } \\
\hline Axillary clearance & 0 & 5 & 14 \\
\hline Sentinel node & 8 & | | & 7 \\
\hline No axillary dissection & I & 4 & 0 \\
\hline Cancer in situ & I & 2 & 0 \\
\hline \multicolumn{4}{|l|}{ No. of involved nodes } \\
\hline$\leqslant 3$ & 0 & 0 & | | \\
\hline $4-8$ & 1 & I & 4 \\
\hline$\geqslant 9$ & 0 & 0 & I \\
\hline negative & 8 & 15 & 5 \\
\hline $\mathrm{ER}+$ & 8 & 17 & 14 \\
\hline $\mathrm{PR}+$ & 8 & 10 & 9 \\
\hline HER2+ & & I & 4 \\
\hline HER2- & & I & 6 \\
\hline Tumour size mm, median & & $14(5-50)$ & $17(7-30)$ \\
\hline $\begin{array}{l}\text { (range) } \\
<2 \mathrm{~cm}\end{array}$ & & & \\
\hline $\begin{array}{l}<2 \mathrm{~cm} \\
\geqslant 2 \mathrm{~cm}\end{array}$ & 2 & $\begin{array}{c}13 \\
7\end{array}$ & $\begin{array}{c}16 \\
5\end{array}$ \\
\hline Adjuvant tamoxifen & 5 & |1 & 15 \\
\hline
\end{tabular}

$(\mathrm{RT}+\mathrm{CT}$ group) with 5-fluorouracil, epirubicin and cyclophosphamide (FEC). Comparable number of patients in both arms received adjuvant tamoxifen therapy at the time of testing.

\section{Monoclonal antibodies and other reagents}

Antibodies conjugated with FITC, PE, PerCP or APC against the surface molecules CD3, CD4, CD8, CD19, CD25, CD28, CD56, CD94, CD161 and NKB1 and the cytokines IFN- $\gamma$, IL-2 and IL-4, as well as isotype-matched negative controls were commercially purchased from Becton-Dickinson (BD) (Mountain view, CA, USA). Mabs against the signal transduction molecules P56 $6^{\mathrm{ck}}$, p59 $9^{\mathrm{fyn}}$, Zap70 and PI3k were purchased from Transduction Laboratories (Lexington, KY, USA) and antibody against CD3 from Bio Site (Stockholm, Sweden). Saponin, PMA and ionomycin were purchased from Sigma (St Louis, MO, USA) and Brefeldin A and goat antimouse $\mathrm{Mab}$ were obtained from $\mathrm{BD}$.

\section{Isolation of peripheral blood mononuclear cells and cell culture conditions}

Peripheral blood mononuclear cells (PBMNC) were isolated from heparinised blood by separation on a Ficoll-Isopaque gradient (Amersham Pharmacia Biotech AB, Uppsala, Sweden). To assess the ability of $\mathrm{T}$ and NK cells to produce cytokines in response to stimuli, $1-2 \times 10^{6}$ cells ml $^{-1}$ were stimulated with $25 \mathrm{ng} \mathrm{ml}^{-1}$ PMA and $1 \mu \mathrm{g} \mathrm{ml}^{-1}$ ionomycin in RPMI-1640 medium containing $10 \%$ heat-inactivated fetal calf serum (FCS), $2 \mathrm{mml}^{-1}$ glutamine, $100 \mathrm{U} \mathrm{ml}^{-1}$ penicillin, $100 \mu \mathrm{g} \mathrm{ml}^{-1}$ streptomycin (Gibco BRL, Paisley, UK) and $10 \mu \mathrm{g} \mathrm{ml}^{-1}$ Brefeldin A in Falcon tubes. Unstimulated samples were set up in parallel, but without PMA and ionomycin. The Falcon tubes were incubated at $37^{\circ} \mathrm{C}$ in a $5 \%$ $\mathrm{CO}_{2}$ for $4 \mathrm{~h}$.

\section{Cellular staining and flow cytometry}

Flow-cytometric analyses were carried out using a FACSCalibur (BD) as described in a previous study (Mozaffari et al, 2004). Fresh cells were used whenever possible, failing which cryopreserved cells, ficolled to remove dead cells and debris, were used. Briefly, $5 \times 10^{5}$ cells per tube were incubated with the appropriate concentration of antibodies or isotype controls $(2-10 \mu \mathrm{l})$ for $30 \mathrm{~min}$ on ice. For indirect staining of intracellular cytokines and signalling molecules, the cells were permeabilised with $0.1 \%$ saponin and incubated with the primary antibodies or isotype controls for $30 \mathrm{~min}$ at room temperature in the dark. Goat antimouse FITC-conjugated secondary antibody was then added to the washed cells and incubated for $10 \mathrm{~min}$. Flow-cytometry gating was used to detect and separate lymphocytes and to analyse the T and NK cells. Criteria for positive staining were set at fluorescent intensities displayed by $<1 \%$ of the cells stained with the isotype controls. Threshold frequencies of cytokine production by unstimulated control cells were subtracted from the percentage of cytokine producing cells quantified after stimulation.

\section{Calculation of absolute cell numbers}

Lymphocytes expressing NK receptors and T-cell subset markers as determined by flow cytometry were expressed as a percentage of the total population. To determine the number of the populations per millilitre of blood, the percentage fraction of lymphocytes was multiplied by the number of lymphocytes per litre as determined by an automated differential blood count on the same sample.

\section{NK- cell-mediated cytotoxicity}

Natural killer cell function was measured in vitro using a chromium release assay. Briefly, NK-sensitive K562 cells were 
labelled with $100 \mu \mathrm{Ci} \mathrm{Na}{ }^{51} \mathrm{CrO}_{4}$ (37 MBq, $1 \mathrm{mCi}$, Amersham, UK) for $1 \mathrm{~h}$ and cocultured with effector cells for $4 \mathrm{~h}$ at various effector: target cell ratios in triplicates in 96-well plates $(50: 1,25: 1,12.5: 1$, $6.25: 1)$. Spontaneous ${ }^{51} \mathrm{Cr}$ release was determined by incubating target cells alone, and total release by lysing labelled cells with $5 \%$ Triton X-100. After incubation the supernatant was counted in a gamma counter. NK cytotoxic activity was calculated as number of lytic units (LU) per $10^{6}$ effector cells. One lytic unit is the number of effector cells capable of lysing $30 \%$ of the target cells and the calculations were performed using computer software kindly provided by Dr T Whiteside (University of Pittsburgh, Pittsburgh, PA, USA).

\section{Proliferation assay}

Mononuclear cells from patients or healthy volunteers $\left(1 \times 10^{5}\right.$ cells well $\left.^{-1}\right)$ were incubated in medium alone, medium containing $10 \mu \mathrm{g} \mathrm{ml}^{-1}$ phytohaemagglutinin (PHA) (Gibco BRL) or $2.5 \mu \mathrm{g} \mathrm{ml}^{-1}$ of mycobacterial purified protein derivative (PPD) (National Serum Institute, Copenhagen, Denmark) in a 96-well culture plate. Cultures were incubated for 3 days and $1 \mu \mathrm{Ci}$ well ${ }^{-1}$ ${ }^{3} \mathrm{H}$-thymidine (Amersham Pharmacia Biotech, Uppsala, Sweden) was added to each well for the final 16-18 h. Cells were harvested and the incorporated radioactivity was measured in a $\beta$-counter (Micro $\beta$ 1450, Wallace, Turku, Finland). Results were reported as stimulation index, calculated as the ratio of radioactivity of cells incubated with PHA or PPD and the radioactivity of control cultures.

\section{Statistical methods}

The Kruskal-Wallis or Mann-Whitney $U$-test was used to calculate statistical significance in expression of cell surface molecules among the four groups of patients. Simple linear regression analysis was used to explore the possible correlation between immunological parameters, for example LU and NK receptors. Results were considered to be statistically significant for $P<0.05$. Data from the phenotypic analyses as well as functional assays from healthy donors and patients had a normal distribution pattern.

\section{RESULTS}

\section{NK cells}

Four-colour flow cytometry demonstrated significantly higher absolute numbers of $\mathrm{NK}$ cells $\left(\mathrm{CD} 3^{-} \mathrm{CD} 56^{+}\right)$in the PT group compared to RT and RT + CT groups as well as to healthy controls. In particular, the RT $+\mathrm{CT}$ group had significantly lower number of NK cells than all other groups (Table 2). The frequency of cells expressing the NK-cell receptors CD161 (Figure 1), NKB1 (Figure 2) and CD94 (not shown) demonstrated the same pattern. There was also a significantly higher NK cytotoxicity in the PT group in comparison to post-treatment group and healthy volunteers, with the lowest cytotoxicity observed in the RT + CT group and in healthy volunteers (Table 2).

Intracellular staining for IFN- $\gamma$ in NK cells revealed comparable patterns to the LU and overall NK frequency. Significantly higher frequency of IFN $\gamma$-producing NK cells was found in patients before treatment compared to all other groups (Table 2).

\section{Analysis of regulatory $\mathrm{T}$ cells and $\mathrm{T}$-cell surface markers}

Both RT and RT + CT had a profound effect in decreasing the numbers of circulating $\mathrm{T}$ cells with $\mathrm{CD} 4{ }^{+}$cells being affected to a greater extent than $\mathrm{CD}^{+}$cells (Table 2). We subsequently analysed the Treg subsets in the patients before and after therapy in comparison to normal donors and also examined the activation markers on $\mathrm{T}$ cells. Tregs were measured as frequency of $\mathrm{CD} 3+\mathrm{CD} 4+\mathrm{CD} 25^{\text {hi }}$ cells (Figure 3). The frequency of

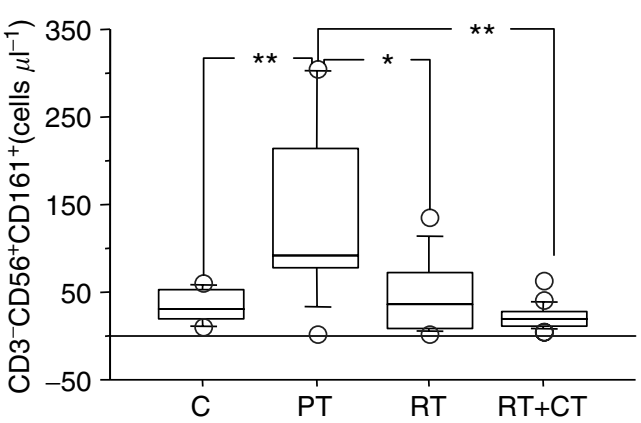

Figure I Absolute number of $\mathrm{CDI} 61^{+} \mathrm{NK}$ cells in normal control donors (C) $(n=\mid \mathrm{I})$, pretreatment (PT) $(n=9)$, post-treatment radiation (RT) $(n=20)$ and post-treatment radiation/chemotherapy (RT $+C T$ ) $(n=21)$ treated breast cancer patients. The box represents the 25 th to 75th percentiles. The line in the middle of the box represents the median. The top whisker is drawn from the value associated with the 75th to the 90th percentile, the bottom one associated with the 25th to the 10th percentile. The outliers show the highest and lowest 10\% of observed values. ${ }^{*} P<0.05$, ${ }^{*} * P<0.01$ and ${ }^{*} * * P<0.001$.

Table 2 Lymphocyte subsets in patients and healthy donors

\begin{tabular}{|c|c|c|c|c|}
\hline & C & PT & RT & $\mathbf{R T}+\mathbf{C T}$ \\
\hline $\mathrm{WBC}^{\mathrm{a}}$ & $6.9 \times 10^{3} \pm 0.4\left(5.6-10 \times 10^{3}\right)$ & $7 \times 10^{3} \pm 0.5\left(4.5-9.2 \times 10^{3}\right)$ & $5.7 \times 10^{3} \pm 0.3\left(4.1-8.5 \times 10^{3}\right)$ & $4.3 \times 10^{3} \pm 0.2\left(3.2-5.3 \times 10^{3}\right)$ \\
\hline Lymphocyte $^{\mathrm{b}}$ & $2 \times 10^{3} \pm 0.2\left(1.1-3 \times 10^{3}\right)$ & $1.9 \times 10^{3} \pm 0.1\left(1.3-2.2 \times 10^{3}\right)$ & $1.7 \times 10^{3} \pm 0.1\left(0.8-3 \times 10^{3}\right)$ & $1.1 \times 10^{3} \pm 0.1\left(0.6-1.7 \times 10^{3}\right)$ \\
\hline $\mathrm{CD}^{+} \mathrm{CD}^{+} \mathrm{C}$ & $858 \pm 107(385-1512)$ & $782 \pm 77(435-1045)$ & $625 \pm 79(230-1572)$ & $336 \pm 24(198-606)$ \\
\hline $\mathrm{CD} 3^{+} \mathrm{CD}^{+}{ }^{d}$ & $37 \mid \pm 76(133-885)$ & $260 \pm 38(102-399)$ & $244 \pm 32(95-447)$ & $311 \pm 39(87-476)$ \\
\hline $\mathrm{CD}^{-} \mathrm{CD}^{-} 6^{+\mathrm{e}}$ & $160 \pm 32(49-410)$ & $293 \pm 47(74-462)$ & $144 \pm 23(10-428)$ & $84 \pm 12(7.7-150)$ \\
\hline IFN- $\gamma+N K$ cell frequency ${ }^{f}$ & $2.1 \pm 0.6(0.0-6.5)$ & $6.2 \pm 0.8(2-9.8)$ & $3.5 \pm 0.6(0.1-10)$ & $4.4 \pm 0.6(1-11)$ \\
\hline LUg & $2.6 \pm 0.4(1-6.6)$ & $13 \pm 2.9(1.9-32.5)$ & $6.6 \pm 1.2(1.3-19.5)$ & $4.4 \pm 0.6(0.3-10.4)$ \\
\hline
\end{tabular}

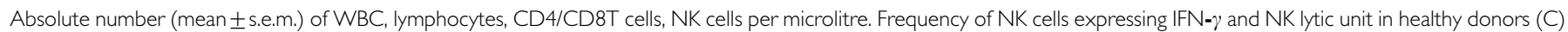

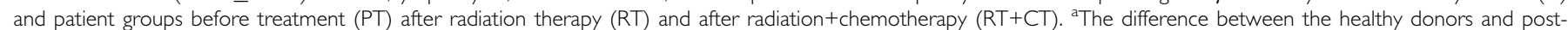

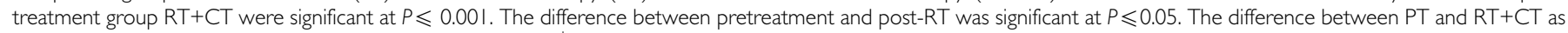

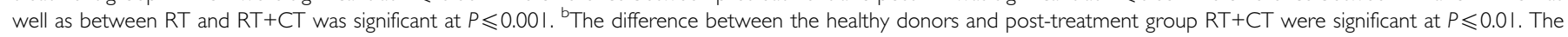

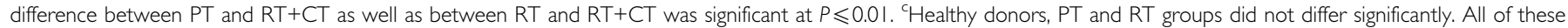

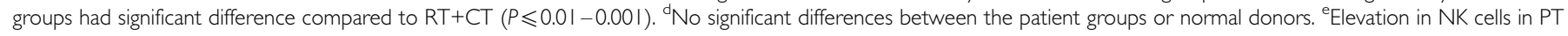

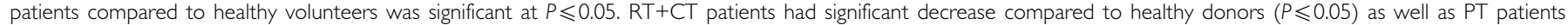

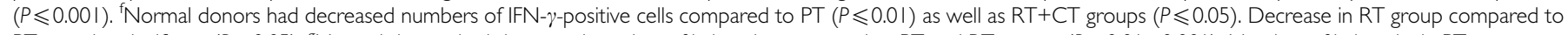

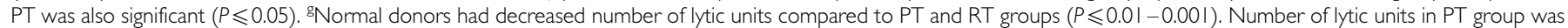
elevated compared to RT $(P \leqslant 0.05)$ as well as RT+CT groups $(P \leqslant 0.0 I)$. 
$\mathrm{CD} 4+\mathrm{CD} 25^{\text {hi }}$ as well as $\mathrm{CD} 8+\mathrm{CD} 25^{\text {hi }} \mathrm{T}$ cells was significantly reduced in pretreatment patients $(P<0.05)$. There was however a significant increase in $\mathrm{CD} 8+\mathrm{CD} 25^{\mathrm{hi}}$ in patients after adjuvant therapy compared to pretreatment (Figure 4). The fraction of $\mathrm{CD}^{2} 8^{+} \mathrm{T}$ cells did not differ between patients before treatment and healthy volunteers. However, patients who had received therapy as in particular the RT $+\mathrm{CT}$ group had a significantly reduced number of $\mathrm{CD} 4+\mathrm{CD} 28+\mathrm{T}$ cells (Figure 5).

\section{Intracellular T-cell signalling molecules}

Patients tested before surgery had similar number of $\mathrm{T}$ cells expressing various signalling molecules as the control donors,

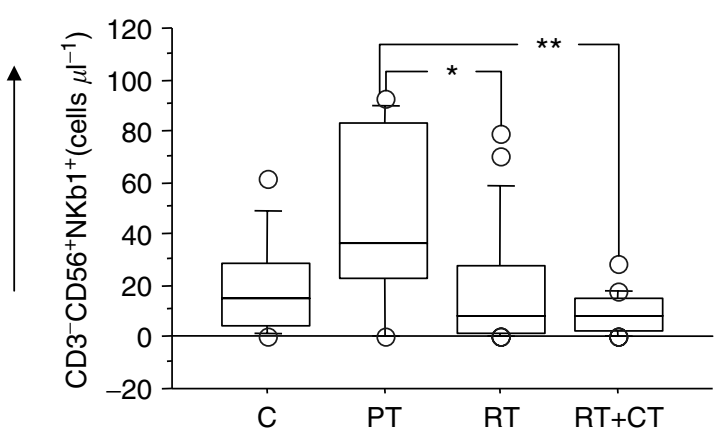

Figure 2 Absolute number of $\mathrm{NKB}{ }^{+} \mathrm{NK}$ cells in normal control donors (C) $(n=11)$, pretreatment (PT) $(n=9)$, post-treatment radiation (RT) $(n=20)$ and post-treatment radiation/chemotherapy $(R T+C T)(n=21)$ treated breast cancer patients. For symbols see Figure I. whereas post-treatment patients, particularly in the RT $+\mathrm{CT}$ group, had a significantly reduced number of $\mathrm{CD}^{+}$cells expressing Zap70, CD3 $\zeta$, P56 ${ }^{\text {lck }}, \mathrm{p} 59^{\text {fyn }}$ and PI3k. There were no significant differences in $\mathrm{CD}^{+} \mathrm{T}$ cells expressing signalling molecules between the groups (data not shown). An example (ZAP70) of the staining pattern of intracellular T-cell signalling molecules in CD4T cells is shown in Figure 6. In addition to frequency of cells, the intensity of expression of the intracellular molecules was also examined using the MFI (mean fluorescence intensity) criterion. In this analysis, these were only marginal differences between the patients groups and controls as exemplified in Figure $7 \mathrm{~A}(\mathrm{CD} 8+\mathrm{CD} 3 \zeta+$ cells $)$ and $\mathrm{B}$ $(\mathrm{CD} 8+$ ZAP70 + cells $)$.

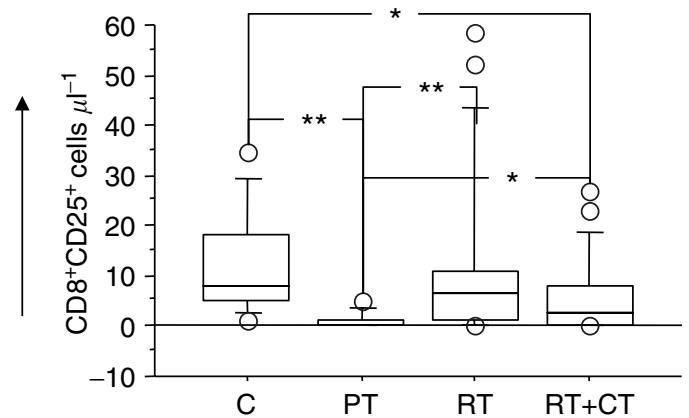

Figure 4 Absolute number of CD25 high expressing CD8 $T$ cells in normal control donors (C) $(n=||)$, pretreatment (PT) $(n=9)$, posttreatment radiation $(\mathrm{RT})(n=20)$ and post-treatment radiation/chemotherapy $(R T+C T)(n=2 I)$ treated breast cancer patients. For symbols see Figure I.
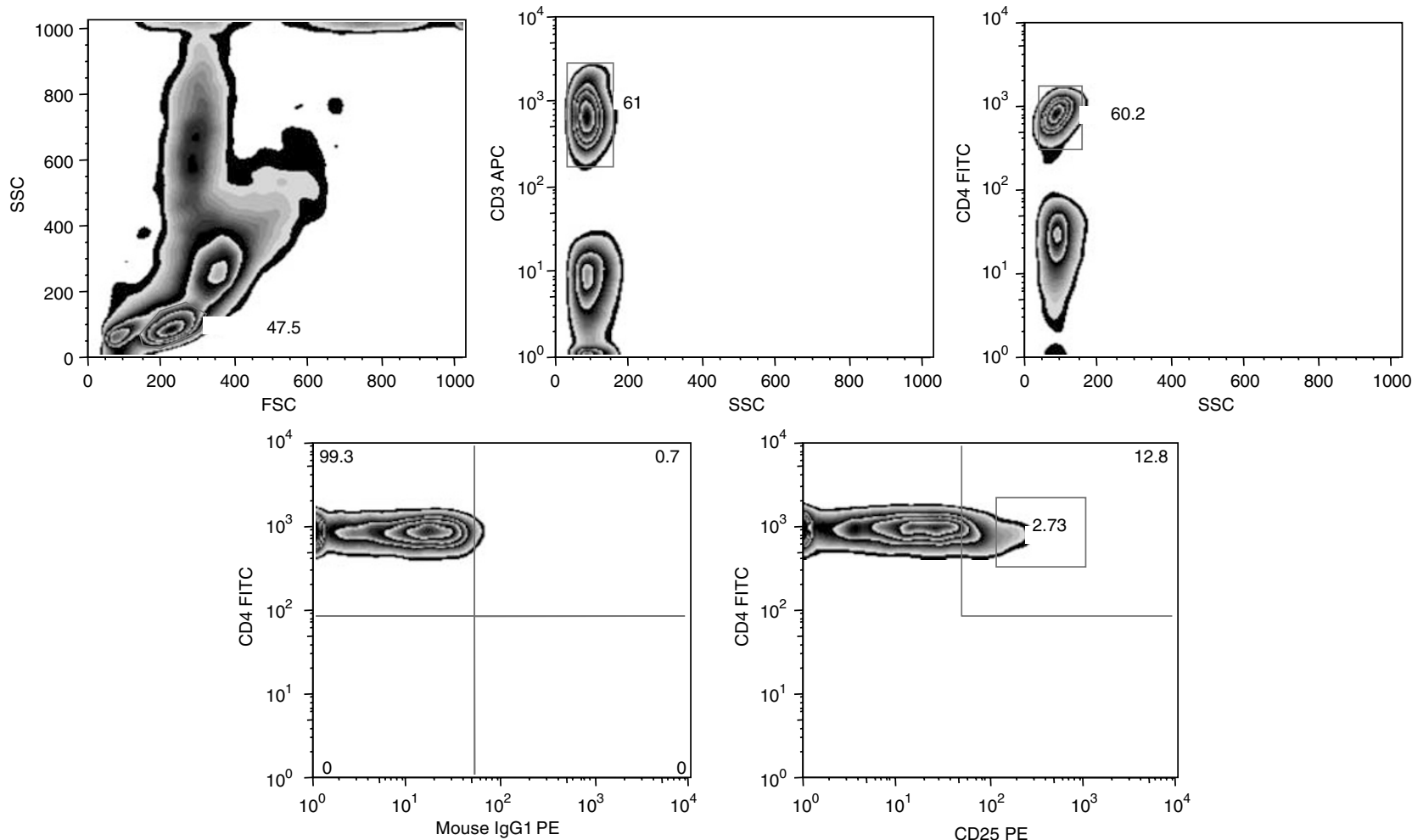

Figure 3 Flow cytometric analysis of $\mathrm{CD} 4{ }^{+} \mathrm{CD} 25^{\text {high }}$ and $\mathrm{CD} 4{ }^{+} \mathrm{CD} 25^{+} \mathrm{T}$ cells in healthy donors and breast cancer patients. A minimum of 20000 events in the lymphocyte gate was calculated during acquisition and the analyses was performed on all events calculated. Numbers in the plot indicate the percentage of cells within the respective rectangle. 


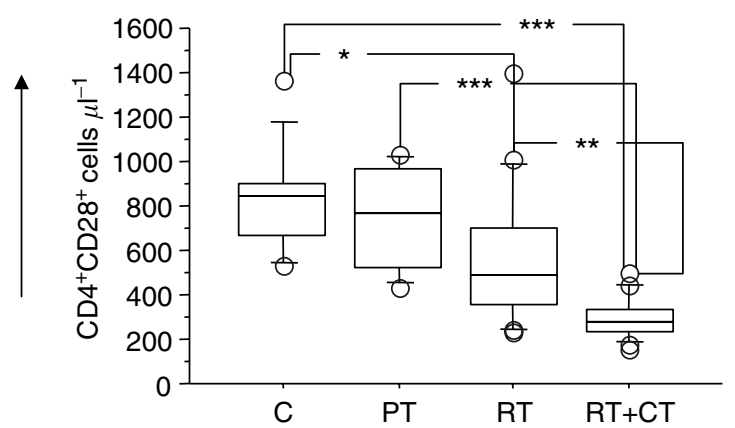

Figure 5 Absolute number of CD28 expressing CD4 T cells in normal control donors $(C)(n=\mid 1)$, pretreatment $(\mathrm{PT})(n=9)$, post-treatment radiation $(\mathrm{RT}) \quad(n=20)$ and post-treatment radiation/chemotherapy $(R T+C T)(n=2 l)$ treated breast cancer patients. For symbols see Figure 1 .

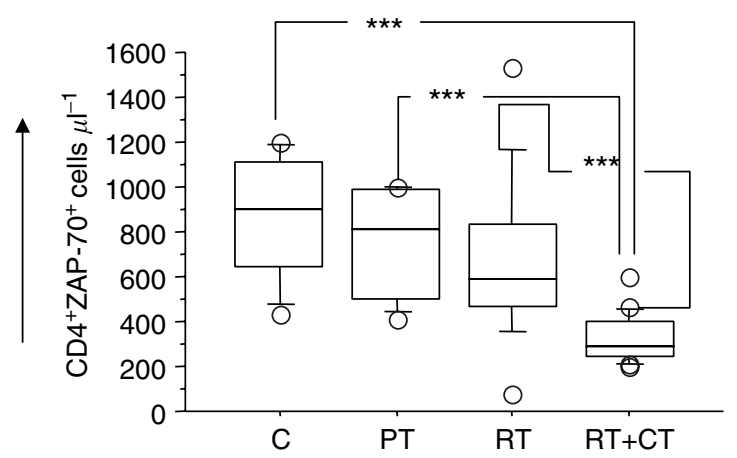

Figure 6 Absolute number of Zap70 expressing CD4 T cells in normal control donors (C) $(n=11)$, pretreatment (PT) $(n=9)$, post-treatment radiation (RT) $(n=20)$ and post-treatment radiation/chemotherapy $(R T+C T)(n=21)$ treated breast cancer patients. For symbols see Figure I.

\section{Intracellular T-cell cytokines}

Frequency of IFN- $\gamma$, IL-4 and IL-2 producing CD4 and CD8T cells was analysed by intracellular staining and flow cytometry following activation of the T cells with PMA/ionomycin. As shown in Figure 8A (CD4) and B (CD8), there was no major difference in IFN- $\gamma$-producing $\mathrm{T}$ cells in patients compared to healthy volunteers, even though patients in RT group demonstrated some reduction in the frequency of IFN- $\gamma$-producing $\mathrm{T}$ cells. The frequency of IL-4-producing CD4 cells was significantly higher in patients before treatment compared to healthy volunteers $(P<$ $0.001)$ and patients who received RT $(P<0.05)$ (Figure 9A). There was no significant differences in IL-4-producing CD8T cells between the groups (data not shown). The pattern of IL-2 production was similar to that of IL-4 and a significantly higher level of IL-2-producing CD4T cells were detected in patients before therapy compared to all other groups $(P<0.01$ to $<0.05)$. There were no significant differences between the groups regarding CD8T cell healthy volunteers $(P<0.01)$ (Figure 9B). Similar results were observed in CD8T cells producing IL-2 (data not shown).

\section{PPD and PHA T-cell response}

There was no difference in response to PPD between healthy volunteers and patients before therapy; however, PPD response was significantly lower in the RT group, when compared to
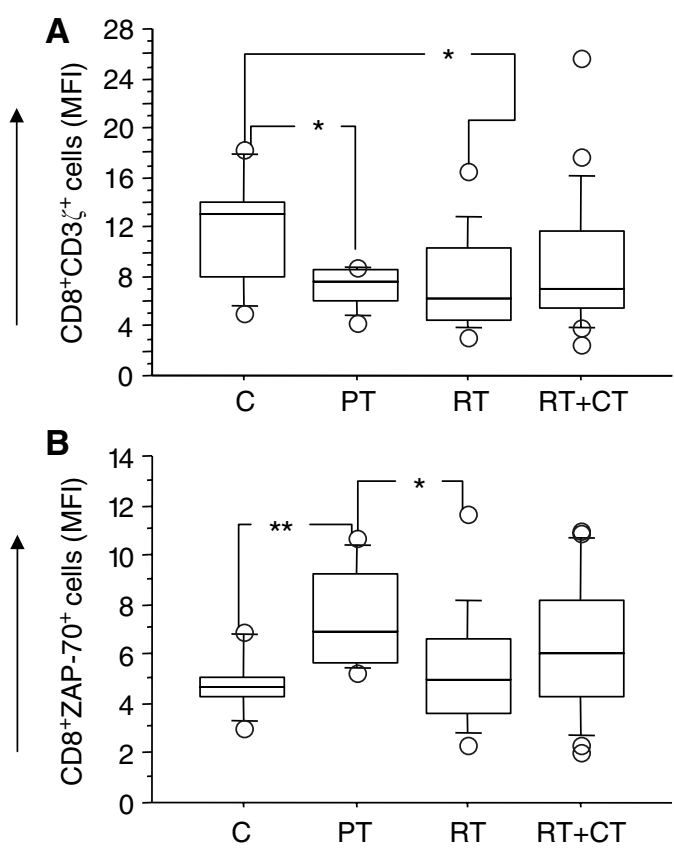

Figure $7 \mathrm{CD} 3 \zeta(\mathbf{A})$ and Zap70 (B) expressing (MFI) CD8 T cells in normal control donors (C) $(n=\mid \mathrm{I})$, pretreatment $(\mathrm{PT})(n=9)$, posttreatment radiation $(\mathrm{RT})(n=20)$ and post-treatment radiation/chemotherapy $(R T+C T)(n=2 \mathrm{I})$ treated breast cancer patients. For symbols see Figure I.
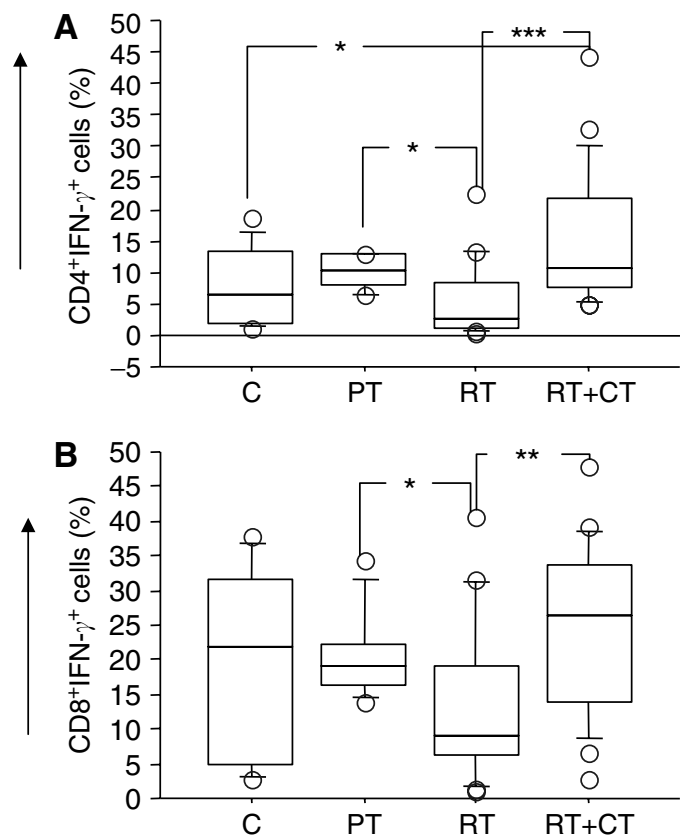

Figure 8 Percentage of IFN- $\gamma$-producing $T$ cells in normal control donors (C) $(n=\mid \mathrm{I})$, Pretreatment (PT) $(n=9)$, post-treatment radiation (RT) $(n=20)$ and post-treatment radiation/chemotherapy (RT +CT) $(n=21)$ treated breast cancer patients. (A) CD4; (B) CD8 T cells. For symbols see Figure I.

patients before treatment $(P<0.05)$. Although an increased level of PHA-induced proliferation response was seen between pretreatment patients and healthy volunteers, the observed difference was not statistically significant (data not shown). 

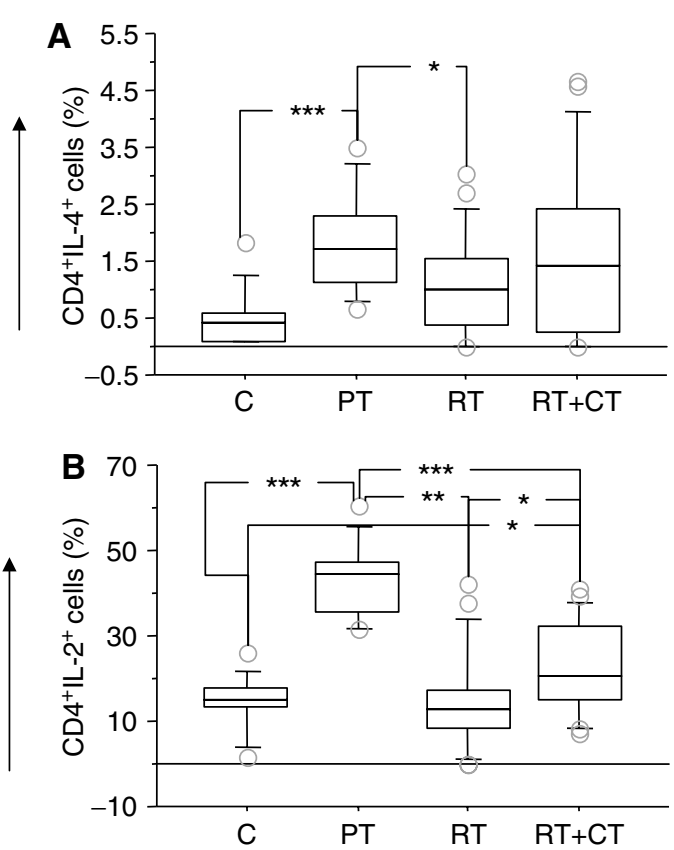

Figure 9 Percentage of IL-4 (A) and IL-2 (B) producing CD4 T cells in normal control donors (C) $(n=||)$, pretreatment $(\mathrm{PT})(n=9)$, posttreatment radiation $(R T)(n=20)$ and post-treatment radiation/chemotherapy $(\mathrm{RT}+\mathrm{CT})(n=2 \mathrm{I})$ treated breast cancer patients. For symbols see Figure I.

\section{DISCUSSION}

There is a great need to develop approaches for primary therapy of solid tumours that preserve immune function since ADCCpromoting therapeutic antibodies, such as trastuzumab and anticancer vaccination, are being increasingly developed as adjuvant treatment modalities (Arnould et al, 2006). With this objective in mind, this study aimed to examine the various aspects of NK- and T-cell functions in pretreatment and post-adjuvant treatment of breast cancer patients.

Untreated breast cancer patients demonstrated increased levels of NK cells in comparison to healthy subjects, but the levels were markedly reduced following therapy in both $\mathrm{RT}$ and $\mathrm{RT}+\mathrm{CT}$ patients. The upregulation was manifested as increased frequency of $\mathrm{CD}^{-} \mathrm{CD}^{-} 6^{+}$cells and increased lytic activity against $\mathrm{K} 562$ targets. Additionally the NK markers CD162, NKB1, CD94 and the number of IFN- $\gamma$-producing NK cells were increased in pretreatment patients which decreased post-therapy. Since lymphocyte counts in pretreatment patients and healthy volunteers were not significantly different, it appears that both the numbers and functional activity of NK cells were increased in patients before treatment. The augmented NK-cell cytotoxicity may be a result of activation of the innate immune system by the malignant process and/or is a result of defective regulation of NK cells in the patients. NK cells are the principal mediators of ADCC (Henney et al, 1981; Rosenberg et al, 1987). Recent work has provided further rationale for maintaining NK function in patients, especially those eligible for monoclonal antibody-based therapeutic regimens. ADCC has been demonstrated to be an important mechanism for the in vivo effects of antibodies like trastuzumab and rituximab (Clynes et al, 2000). Although NK cells are important effectors of ADCC, their ability to function in ADCC may be reduced with advanced malignancy (Kono et al, 2002) as well as following radiochemotherapy (present study), possibly owing to defective expression of NK cell-triggering receptors (Costello et al, 2002). Our data and these previously published studies suggest the use of early, rather than late, adjuvant therapy treatment protocols for patients with breast cancer.
As expected, patients had a significant decrease in circulating $\mathrm{T}$ cells after therapy, with helper $\mathrm{T}$ cells being affected to a greater extent than cytotoxic $\mathrm{T}$ cells. However, the low numbers of circulating $\mathrm{CD} 4^{+} \mathrm{CD} 25^{\text {high }}$ as well as $\mathrm{CD} 8^{+} \mathrm{CD} 25^{\text {high }}$ in patients before treatment was a surprising finding and in contrast to earlier reports (Liyanage et al, 2002), showing an increased proportion of $\mathrm{CD} 4{ }^{+} / \mathrm{CD} 25^{+}$cells in breast and pancreatic cancer patients. Some of the contributing factors leading to the discrepant results may be diverse patient characteristics as well as the fact that we calculated the results as absolute number of the cells rather than percentage frequency. The increased production of IL-2 following in vitro stimulation of cells from patients before treatment may also be due to the low absolute numbers of $\mathrm{CD} 4{ }^{+} \mathrm{CD} 25^{+} \mathrm{T}$ cells and, consequently, lesser inhibitory activity. The absolute numbers of $\mathrm{CD} 4{ }^{+} \mathrm{CD} 25^{+} \mathrm{T}$ cells as well as $\mathrm{CD} 4^{+} \mathrm{CD} 25^{\text {high }}$ did not change significantly following treatment but a significant increase in the number of $\mathrm{CD} 8{ }^{+} \mathrm{CD} 25^{+} \mathrm{T}$ cells as well as $\mathrm{CD} 8^{+} \mathrm{CD} 25^{\text {high }}$ was observed compared to patients before therapy. It is interesting to notice that RT has an effect on increasing the absolute number of $\mathrm{CD} 4^{+} \mathrm{CD} 25^{\text {high }}$ and specifically on $\mathrm{CD} 8^{+} \mathrm{CD} 25^{\text {high }} . \mathrm{CD} 8^{+} \mathrm{CD} 25^{\text {high }}$ cells are also known to serve as regulatory $\mathrm{T}$ cells quite like their $\mathrm{CD}^{+}{ }^{+} \mathrm{CD} 25^{+}$counterparts (Bisikirska et al, 2005; Maggi et al, 2005).

An interesting observation was that $\mathrm{RT}+\mathrm{CT}$ treatment had better preservation of IFN- $\gamma$ secretion by $\mathrm{CD} 4^{+}$and $\mathrm{CD} 8^{+}$cells as well as better preservation of IL- 2 secretion by $\mathrm{CD}^{+}$cells compared to RT arm. While the exact mechanism is not known, studies in animal models have shown that a single administration of cyclophosphamide biases the immune system in favour of a Th1 response and facilitates the secretion of cytokines such as IL-2 and IFN- $\gamma$ (Matar et al, 2002). The striking similarity of our results demonstrating that RT + CT patients had higher levels of IL-2 and IFN- $\gamma$-secreting $\mathrm{T}$ cells leads us to speculate that the cyclophosphamide included in the FEC regimen may be responsible for this effect.

The ability of $\mathrm{T}$ cells to transduce signals to the nucleus following engagement of the TCR is a key component in the initiation of an immune response. The intracellular downstream signalling molecules, CD3 $\zeta$, Zap70, P56 $6^{\mathrm{lck}}$, p59 $9^{\mathrm{fyn}}$ and PI3k, were significantly reduced in the patients following treatment and the reduction was more pronounced in radiation/chemotherapy patients. There was no significant difference in frequencies of signalling molecules in patients before therapy, compared to healthy volunteers. However, the intensity of $\mathrm{CD} 3 \zeta$ expression in CD8T cells measured as MFI was significantly downregulated. Zap70 showed a significant upregulation in $\mathrm{T}$ cells in patients before treatment, compared to healthy volunteer, which further contributed to the defective T-cell function in breast cancer patients. Our result support and extend the previous findings of Kurt et al (1998), who demonstrated decreased P56 ${ }^{\text {lck }}$, CD3 $\zeta$ and Zap70 protein expression in 4 of 14 breast cancer patients. However, in contrast to our study, 10 of 14 patients were in stage IV disease and had been previously treated with chemotherapy or hormonal therapy. Moreover, the signalling molecules were examined in our study using flow cytometry, a technique known to be more sensitive and quantitative compared to western blotting used in the report of Kurt et al (1998). Our data also indicate that T-cell function was negatively affected by treatment, especially in the RT $+\mathrm{CT}$ group. It has been previously shown that cytotoxic T-cell number correlate with clinical prognosis in breast cancer patients (Blake-Mortimer et al, 2004) and that localised radiation can cause transiently a systemic effect on T-cell function (Berger et al, 1990). Treatment strategies dependent on the integrity of T-cell function, such as vaccination approaches (Morse, 2000), could potentially be more efficacious if initiated before radio-chemotherapy, or following recovery of $\mathrm{T}$-cell function after cessation of therapy. 
Current research on immunotherapy for cancer mainly focuses on optimal use of monoclonal antibodies and on generation of T-cell-mediated immunity by vaccination strategies. Thus, the negative effects of radiation and/or chemotherapy on NK- and $\mathrm{T}$-cell activity in breast cancer are worth considering when new antibody and vaccine trials are designed in patients with breast cancer.

\section{REFERENCES}

Arnould L, Gelly M, Penault-Llorca F, Benoit L, Bonnetain F, Migeon C, Cabaret V, Fermeaux V, Bertheau P, Garnier J, Jeannin JF, Coudert B (2006) Trastuzumab-based treatment of HER2-positive breast cancer: an antibody-dependent cellular cytotoxicity mechanism? Br J Cancer 94: $259-267$

Bauernhofer T, Kuss I, Henderson B, Baum AS, Whiteside TL (2003) Preferential apoptosis of CD56dim natural killer cell subset in patients with cancer. Eur J Immunol 33: 119-124

Berger M, Irschick E, Fritsch E, Frommhold H, Schonitzer D, Wiegele J, Kemmler G, Huber C (1990) Influence of local radiotherapy of breast cancer patients on the frequency of cytotoxic $\mathrm{T}$ lymphocyte precursor cells. Immunobiology 180: $261-271$

Bisikirska B, Colgan J, Luban J, Bluestone JA, Herold KC (2005) TCR stimulation with modified anti-CD3mAb expands $\mathrm{CD} 8+\mathrm{T}$ cell population and induces CD8+CD25+Tregs. J Clin Invest 115: 2904-2913

Blake-Mortimer JS, Sephton SE, Carlson RW, Stites D, Spiegel D (2004) Cytotoxic $\mathrm{T}$ lymphocyte count and survival time in women with metastatic breast cancer. Breast J 10: 195-199

Bray F, McCarron P, Parkin DM (2004) The changing global patterns of female breast cancer incidence and mortality. Breast Cancer Res 6: $229-239$

Caras I, Grigorescu A, Stavaru C, Radu DL, Mogos I, Szegli G, Salageanu A (2004) Evidence for immune defects in breast and lung cancer patients. Cancer Immunol Immunother 53: 1146-1152

Chan A, Martin M, Untch M (2006) Vinorelbine plus trastuzumab combination as first-line therapy for HER 2-positive metastatic breast cancer patients: an international phase II trial. Br J Cancer 95: 788-793

Cheng F, Gabrilovich D, Sotomayor EM (2004) Immune tolerance in breast cancer. Breast Dis 20: $93-103$

Clynes RA, Towers TL, Presta LG, Ravetch JV (2000) Inhibitory Fc receptors modulate in vivo cytoxicity against tumor targets. Nat Med 6: $443-446$

Costello RT, Sivori S, Marcenaro E, Lafage-Pochitaloff M, Mozziconacci MJ, Reviron D, Gastaut JA, Pende D, Olive D, Moretta A (2002) Defective expression and function of natural killer cell-triggering receptors in patients with acute myeloid leukemia. Blood 99: 3661-3667

Gennari R, Menard S, Fagnoni F, Ponchio L, Scelsi M, Tagliabue E, Castiglioni F, Villani L, Magalotti C, Gibelli N, Oliviero B, Ballardini B, Da Prada G, Zambelli A, Costa A (2004) Pilot study of the mechanism of action of preoperative trastuzumab in patients with primary operable breast tumors overexpressing HER2. Clin Cancer Res 10: 5650-5655

Henney CS, Kuribayashi K, Kern DE, Gillis S (1981) Interleukin-2 augments natural killer cell activity. Nature 291: 335-338

Hudis CA (2003) Current status and future directions in breast cancer therapy. Clin Breast Cancer, 4 Suppl 2: S70-S75

\section{ACKNOWLEDGEMENTS}

We thank Ms Birgitta Hagström for expert technical help and Ms Leila Relander for assistance. This study was supported by grants from Sparbanksstiftelsen Nya, Västerås, Cancer and Allergy Foundation, the Research Foundation of Vastmanland, Cancer and Traffic Injury Fund, County Council of Vastmanland.

Konjevic G, Spuzic I (1992) Evaluation of different effects of sera of breast cancer patients on the activity of natural killer cells. J Clin Lab Immunol 38: $83-93$

Kono K, Takahashi A, Ichihara F, Sugai H, Fujii H, Matsumoto Y (2002) Impaired antibody-dependent cellular cytotoxicity mediated by herceptin in patients with gastric cancer. Cancer Res 62: 5813-5817

Kurt RA, Urba WJ, Smith JW, Schoof DD (1998) Peripheral T lymphocytes from women with breast cancer exhibit abnormal protein expression of several signaling molecules. Int J Cancer 78: 16-20

Liljefors M, Nilsson B, Hjelm Skog AL, Ragnhammar P, Mellstedt H, Frodin JE (2003) Natural killer (NK) cell function is a strong prognostic factor in colorectal carcinoma patients treated with the monoclonal antibody 17-1A. Int J Cancer 105: 717-723

Liyanage UK, Moore TT, Joo HG, Tanaka Y, Herrmann V, Doherty G, Drebin JA, Strasberg SM, Eberlein TJ, Goedegebuure PS, Linehan DC (2002) Prevalence of regulatory $\mathrm{T}$ cells is increased in peripheral blood and tumor microenvironment of patients with pancreas or breast adenocarcinoma. J Immunol 169: 2756-2761

Maggi E, Cosmi L, Liotta F, Romagnani P, Romagnani S, Annunziato F (2005) Thymic regulatory T cells. Autoimmun Rev 4: 579-586

Matar P, Rozados VR, Gervasoni SI, Scharovsky GO (2002) Th2/Th1 switch induced by a single low dose of cyclophosphamide in a rat metastatic lymphoma model. Cancer Immunol Immunother 50: 588-596

Morse MA (2000) Technology evaluation: Theratope, Biomira Inc. Curr Opin Mol Ther 2: $453-458$

Mozaffari F, Hansson L, Kiaii S, Ju X, Rossmann ED, Rabbani H, Mellstedt H, Osterborg A (2004) Signalling molecules and cytokine production in $\mathrm{T}$ cells of multiple myeloma-increased abnormalities with advancing stage. Br J Haematol 124: $315-324$

Murta EF, de Andrade JM, Falcao RP, Bighetti S (2000) Lymphocyte subpopulations in patients with advanced breast cancer submitted to neoadjuvant chemotherapy. Tumori 86: $403-407$

Nicolini A, Ferrari P, Spinelli R, Carpi A, Sagripanti A, Ambrogi F (1996) Cell-mediated immunity in breast cancer patients. Biomed Pharmacother 50: $337-343$

Rosenberg SA, Lotze MT, Muul LM, Chang AE, Avis FP, Leitman S, Linehan WM, Robertson CN, Lee RE, Rubin JT (1987) A progress report on the treatment of 157 patients with advanced cancer using lymphokine-activated killer cells and interleukin-2 or high-dose interleukin-2 alone. $N$ Engl J Med 316: 889 -897

Yi H, Rong Y, Yankai Z, Wentao L, Hongxia Z, Jie W, Rongyue C, Taiming L, Jingjing L (2006) Improved efficacy of DNA vaccination against breast cancer by boosting with the repeat beta-hCG C-terminal peptide carried by mycobacterial heat-shock protein HSP65. Vaccine 24: $2575-2584$ 